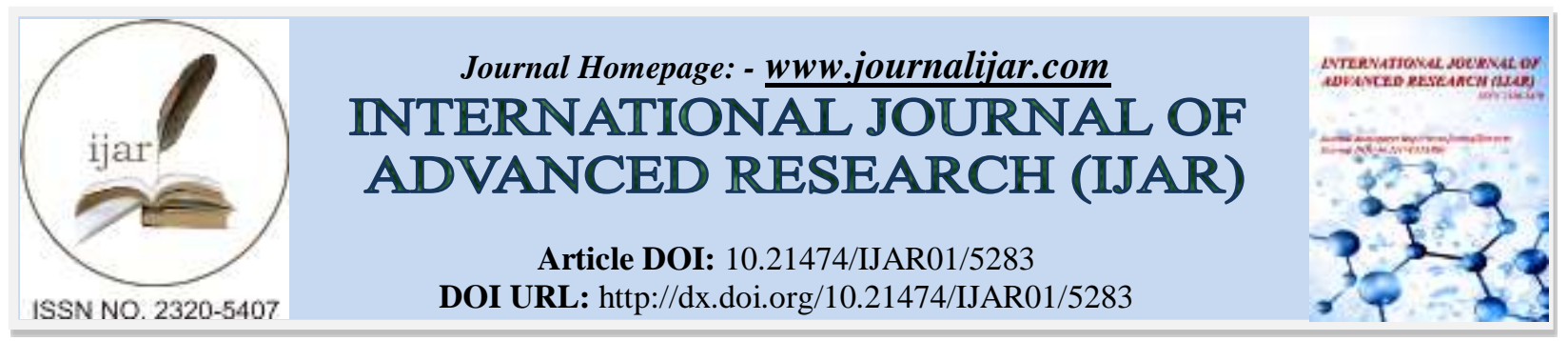

RESEARCH ARTICLE

\title{
ISOLATION OF FILAMENTOUS FUNGI IN POST-HARVEST CEREAL GRAIN DURING THE STORAGE AND THEIR EFFECT ON SEED HEALTH.
}

\author{
Varsha A. Bhalerao and Ashok M. Chavan. \\ Seed Pathology and Fungal Biotechnology Laboratory, Department of Botany, Dr. Babasaheb Ambedkar \\ Marathwada University, Aurangabad.
}

\section{Manuscript Info}

Manuscript History

Received: 25 June 2017

Final Accepted: 27 July 2017

Published: August 2017

Key words:-

Fungi, Cereals, Seed Mycoflora,

Contamination, Germination.

\begin{abstract}
A study conducted to determine the fungi associated with important cereal crop in storage. They were Wheat (Triticum aestivum), Maize (Zea mays), Millet (Pennisetum typhoiodes) and Sorghum (Sorghum vulgare Pers.), collected from a storage. A total number of 96 seed samples, 5 seed samples of each species were collected during 20152016, from Marathwada region. We analyze Mycological of seed by the agar plating method on Potato Dextrose Agar (PDA).Medium and Standard Blotter Method (SBM), revealed the occurrence of 21 diverse fungal species belonging to 9 genera. The fungal species isolated were Aspergillus flavus, Fusarium graminearam, Rhizopus spp., Alternaria alternata, Penicillium sp, Aspergillus niger, Curvularia lunata, Rhizopus stolonifer, Fusarium oxysporum and Mucus sp., among the two methods, the agar paper method was found to be suitable as in less incubation; there was a higher percent incidence of Filamentous fungi. Maize seed samples show maximum incidence of Aspergillus flavus, A. niger and A. fumigattus. Sorghum seed show the maximum percent incidence of various fungi as compare to other Cereals samples. All fungi affected adversely to seed health of the test. The effect of 10 dominant seed-borne fungi on seed health studied by germination methods. The dominant seed-borne fungi affected adversely to seed health; namely, seed germination of the Maize seed samples.
\end{abstract}

Copy Right, IJAR, 2017,. All rights reserved.

\section{Introduction:-}

India is the world's second largest producer of cereals. The huge demand for cereals in the global market is creating an excellent environment for the export of Indian cereal products. In 2008, India had imposed ban on export of rice and wheat. to meet domestic needs. Cereal grains contain 66-76\% carbohydrates, and far the most abundant group of constituents. The major carbohydrate is starch (55-70\%) followed by minor constituents such as Arabinoxylans $(1.5-8 \%)$, b - Glucans $(0.5-7 \%)$, Sugars $(\sim 3 \%)$, Cellulose $(\sim 2.5 \%)$, and Glucofructans $(\sim 1 \%)$. Cereals and derived products represent an important nutrient source for human kind world-wide. In cereal grains loss in quality and quantity during storage is caused by fungi, insects, rodents and mites. Respiration may in certain cases contribute to a loss of dry matter during grain storage.

A major problem of agricultural production is loss of grain during storage and after harvest. Microorganisms, insects, and rodents contribute greatly to these postharvest losses. A commonly quoted estimate provided by the 
FAO for worldwide losses for all cereals, leguminous seeds, and oilseeds is 10\% (Janicki and Green 1976, Christensen and Kaufmann et al., 1974) state that fungi are the major cause of spoilage in stored grains. After the crop harvested, it undergoes several operations that, if improperly done, may result in serious losses (Laubscher \& Cairns, 1983; Giga, 1987; Jonsson \& Kashweka, 1987; Gwinner et al., 1996). India experiences severe losses in storage of food grains, as per the official records economic loss to the tune of 11,700 tons of food grains was reported to have occurred in the government godowns during 2010 alone (Chahal, 2011). However, details on the role of seed born fungi and their metabolites in the deterioration of seed quality and viability are meagre. The effective management can only be implemented effectively if the pathogens are correctly identified. It is in view of this that the current study aimed at detecting seed borne pathogens on cereals seeds.

In present work isolation of mycoflora, using recent techniques, from the seeds at their various developmental stages, collected from different field of Marathwada region. Fungi were isolated from the naturally discoloured, rotten, immature and shriveled seeds, collected from the various storage houses. Effect of dominant seed-borne fungi on seed health of was studied by germination methods.

\section{Materials And Methods:-}

\section{Study Area \& Collection Of Seed Samples:-}

The study was conducted at Aurangabad University, and the samples are collected from the Marathwada region in Aurangabad, Beed, Jalna, Latur, Nanded, Parbhani, Osmanabad and Hingoli. The experimental site is located at in Marathwada region.

Infected cereal grain was collected from different in given regions. Accordingly samples were collected from farmers' Fields, farmer's stores, and from rural and urban markets, Hence, a total of 96 samples were collected from the various cereals seed sources. The samples were placed in cloth bags to allow air circulation that reduced condensation and limited fungal growth after sampling until

\section{Experimental Materials, Treatments and Design:-}

This experiment was designed to isolate fungal pathogens associated on stored maize grain of different varieties with surface disinfecting and without disinfecting. The sample seeds of the varieties were collected from the Marathwada regions. A study was conducted to determine the fungi associated with important cereal crop in storage.

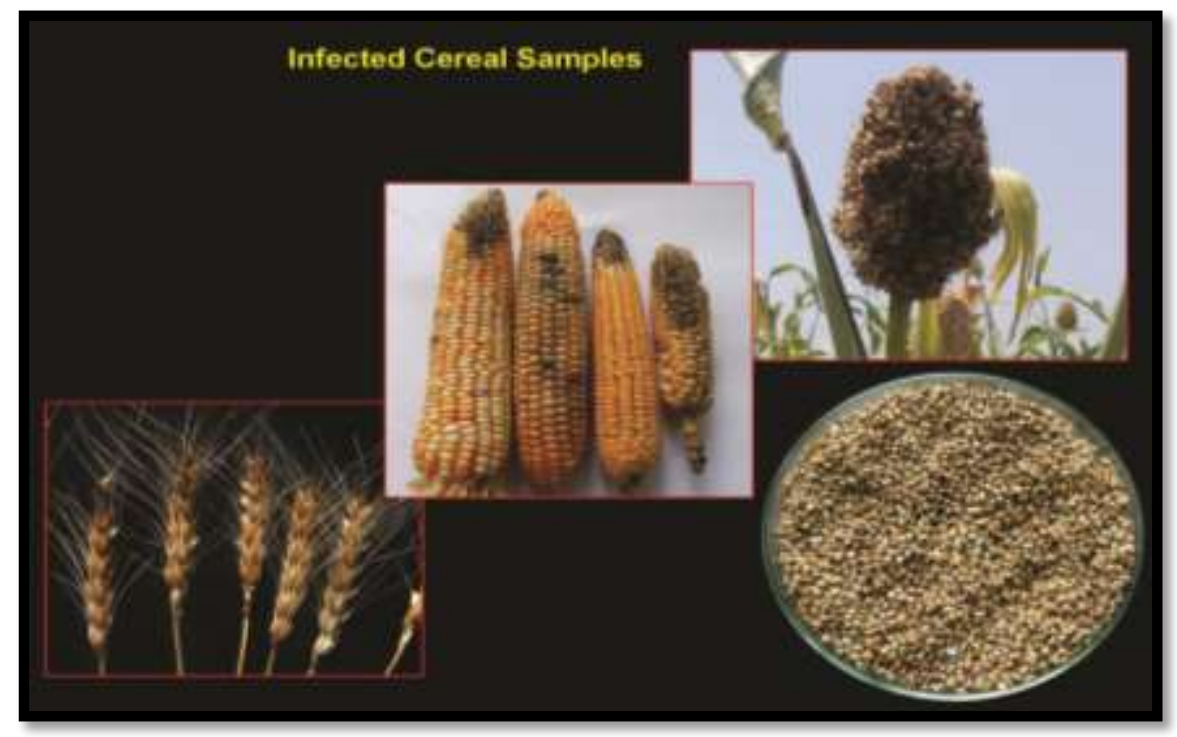

They were Wheat (Triticum aestivum), maize (Zea mays), millet (Pennisetum typhoiodes) and Sorghum (Sorghum vulgare Pers.), which were collected from a storage. A total of 96 seed samples, 5 of each species were collected during 2015-2016. Seed samples collected from Marathwada regain were mycological analyzed by agar plating method on Potato Dextrose Agar (PDA). Medium and Standard Blotter Method (SBM), revealed the occurrence of 21 diverse fungal species belonging to 9 genera. Seeds of each sample were placed on three layers of moistened blotters placed in $90 \mathrm{~mm}$ diam., Petri plates @ 25 seeds/plate. The plates were incubated for 7 days at $20^{\circ} \mathrm{C} \pm 1{ }^{\circ} \mathrm{C}$. Then were examined under the microscope for seed borne mycoflora Incubation tests. 
The plates were incubated at $25 \pm 1{ }^{\circ} \mathrm{C}$ for seven days and then the incubated seeds were studied under a stereomicroscope for identification of fungi (Mathurand Kongsdal, 2003; Habib et al., 2011). Infection levels were recorded as the percentage of infected seeds in each sample.

\section{Blotter method:-}

In this method, similar washing and surface disinfecting producers of agar plate were followed. For this method a total of 96 seed samples, 5 of each species, were collected during 2015-2016. Seed samples collected from Marathwada regain, were mycological analyzed by agar plating method on Potato Dextrose Agar (PDA).Medium and Standard Blotter Method (SBM), revealed the occurrence of 21 diverse fungal species belonging to 9 genera.

Then each blotter plats were incubated under ultraviolet light in alternating cycles of $12-\mathrm{h}$ light/darkness for 7 days at $20^{\circ} \mathrm{C}$. Finally each petri dish (blotter plate) were examined under stero-binocular microscope for fungi isolation based on identification key and each fungal colonies were recorded. In addition to fungal isolation, germination percentage of each blotter was recorded after three and seven days of incubation.

\section{Agar plate method:-}

For this method, seeds three maize variety kernels with and without surface disinfecting were used and some of grains of each treatment were aseptically placed on potato dextrose agar (PDA) plate according to McGee procedures. Three whatman filter papers kept on each other as a layer were moistened and placed in $90 \mathrm{~mm}$ diameter sterilized Petri dish. Hundred seeds of each sample were separated and placed at the rate of 10 seeds per plate. To remove the chemical from the chemically treated seed of BH660 kernels were thoroughly washed in running water. For the surface disinfecting treatments, maize kernel sample was surface disinfected by $1 \%$ Sodium hypochlorite for one minute and rinsed three times in sterile distilled water for 30 seconds each. From both surface disinfected and non-disinfected samples, 10 kernels per petri-plate $(9 \mathrm{~cm}$ diameter plates) containing PDA (potato dextrose agar) were aseptically placed. The plates were incubated at $25 \pm 1{ }^{\circ} \mathrm{C}$ for 7 days and the growth stage of colonies was determined periodically. Finally after 7 days of incubation, the total number of fungal colonies, frequency of isolation of fungi $(\%)$, relative density of isolated fungi $(\%)$ and incidence of fungi $(\%)$ were recorded and calculated.

After the incubation period, each Petri dish was examined under a stereomicroscope in order to record the incidence of different seed-borne fungi. Primary identification of fungi grown on the wheat seeds was performed on the basis of their typical colony characteristics and conidial morphology. The percentage of seed infection in each sample and the percentage of infection in each region were determined by the following formulae,

$$
\text { Percentage Incidence }(\%)=\left(\frac{\text { No. of seeds bearing fungul colonies }}{\text { Total number of seeds examined }}\right) \times 100
$$

\section{Preparation of spore suspension:-}

Spore suspension of dominant seed-borne fungi of cereals were prepared separately by adding $10 \mathrm{ml}$ of sterile distilled water into the sporulating pure cultures of seed-borne fungi maintained on PDA slants for seven days at room temperature. The slants were shaken and content filtered through muslin cloth to separate mycelium and spore. The filtrate thus obtained was used as spore suspension.

\section{Seed germination method:-}

In order to evaluate the effect of seed-borne fungi on percent seed germination, shoot and root length, the seeds of the test cereals was infested separately with spore suspension of dominant seed-borne fungi. These seeds were incubated in sterilized moist blotters at room temperature for seven days. After incubation period, percent seed germination, shoot and root length of each seeds of pulse was recorded.

\section{Result and discussion:-}

In this experimental work, higher significant difference of total fungal colonies among and within different treatment cereals varieties and two surface disinfectants on both agar plate and blotter method was recorded. The 
results obtained in the present study showed high degree of fungal contamination of cereals seed from the observations (table 1), 7 different fungal members were observed in all the localities from Marathwada region, Aspergillus $s p$ was the most frequently isolated fungus.

Table 1:- The Percentage Samples Containing Identified Fungal Genera

\begin{tabular}{|l|l|l|}
\hline Sr. No. & $\begin{array}{l}\text { Identified Fungal } \\
\text { Genera }\end{array}$ & $\begin{array}{l}\text { Percentage Samples } \\
(\mathbf{\%})\end{array}$ \\
\hline & & \\
\hline 1. & Alternaria species & 13.62 \\
\hline 2. & Aspergillus species & 46.00 \\
\hline 3. & Curvularia species & 19.25 \\
\hline 4. & Fusarium species & 14.08 \\
\hline 5. & Penicillium species & 11.50 \\
\hline 6. & Rhizoctonia species & 31.00 \\
\hline 7. & Other species & 5.00 \\
\hline
\end{tabular}

\section{PERCENTAGE SAMPLES CONTAINING IDENTIFIED FUNGAL GENERA}

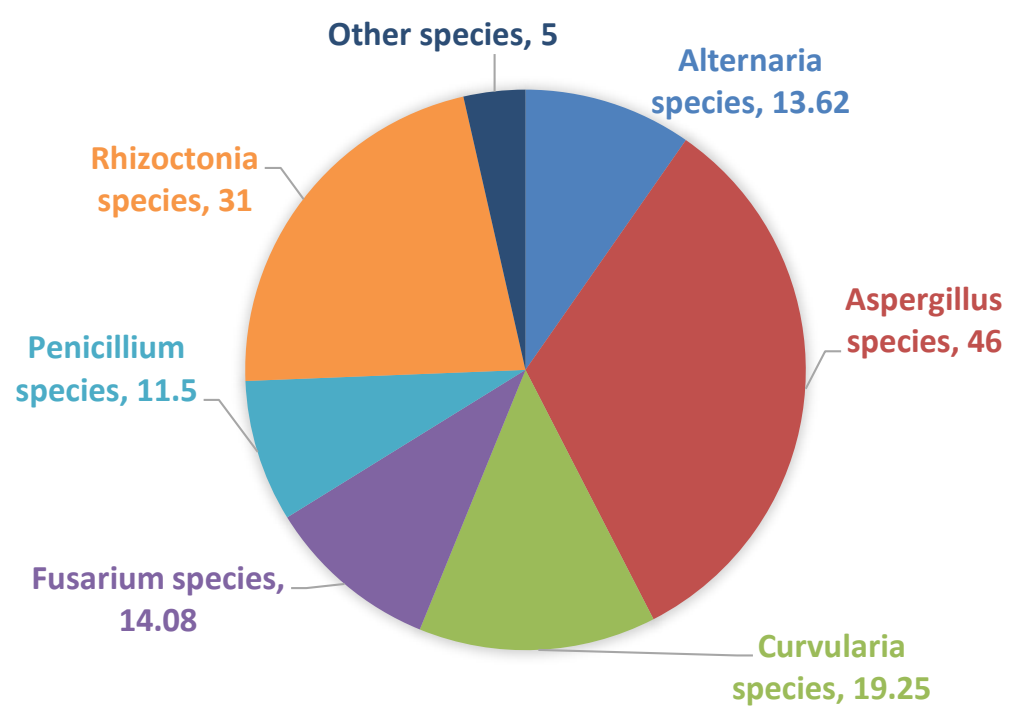

The study shows that all the grains were infested to various degrees with storage fungi. A total of 21 different fungi namely, Alternaria alternata, Penicillium sp, Aspergillus Niger, A. flavus Curvularia lunata, Rhizopus stolonifer, Fusarium oxysporum and Mucus species were isolated from the four grains studied. Aspergillus was the most frequently isolated fungus followed by Aspergillus niger A. flavus. Aspergillus fumigatus, Aspergillus parasiticus, Aspergillus ochraceus, were equally frequent in the grains. Maize (Zea mays) And Sorghum (Sorghum vulgare Pers.) Was the most infested of the grains assayed with the maize being slightly more infested than the millet was the least infested. Maximum incidence were shown by Aspergillus flavus (40\%), Aspergillus niger (54\%) and Curvularia lunata (43\%) in Marathwada region. Rhizopus solani (46\%) and Aspergillus niger (54\%) shows the highest incidence. 
Table 2:- Percentage (\%) of incidence of fungi association at different cereals of grain

\begin{tabular}{|c|c|c|c|c|}
\hline Fungi Name & Maize & Wheat & Bajra & Jowar \\
\hline Alternaria alternata & 18 & 21 & - & 38 \\
\hline $\begin{array}{l}\text { Alternaria } \\
\text { macrospora }\end{array}$ & - & 10 & 12 & 10 \\
\hline Aspergillus flavus & 40 & 8 & 29 & 31 \\
\hline $\begin{array}{l}\text { Aspergillus } \\
\text { fumigatus }\end{array}$ & 20 & - & - & 10 \\
\hline Aspergillus niger & 54 & 40 & 42 & 48 \\
\hline Aspergillus terreus & 12 & 6 & 14 & 25 \\
\hline $\begin{array}{l}\text { Aspergillus } \\
\text { parasiticus }\end{array}$ & 15 & 10 & 8 & 22 \\
\hline $\begin{array}{l}\text { Aspergillus } \\
\text { ochraceus }\end{array}$ & 10 & 36 & 10 & 20 \\
\hline $\begin{array}{l}\text { Cladosporium } \\
\text { herbaroides }\end{array}$ & 5 & 14 & 11 & 15 \\
\hline Curvularia lunata & 20 & 5 & 10 & 10 \\
\hline Fusarium equiseti & - & 11 & 5 & 8 \\
\hline $\begin{array}{l}\text { Fusarium } \\
\text { graminearam }\end{array}$ & 2 & 18 & - & - \\
\hline $\begin{array}{l}\text { Fusarium } \\
\text { oxysporum }\end{array}$ & 22 & 11 & - & 48 \\
\hline $\begin{array}{l}\text { Fusarium } \\
\text { moniliforme }\end{array}$ & 14 & 6 & 28 & 20 \\
\hline Helminthosporium & 20 & 5 & 16 & 28 \\
\hline Mucor & 15 & 10 & 12 & - \\
\hline $\begin{array}{l}\text { Penicillium } \\
\text { citrinum }\end{array}$ & - & 34 & - & 42 \\
\hline $\begin{array}{l}\text { Penicillium } \\
\text { islandicum }\end{array}$ & 10 & 15 & - & 20 \\
\hline $\begin{array}{l}\text { Penicillium } \\
\text { expansum }\end{array}$ & 12 & 10 & - & 10 \\
\hline $\begin{array}{l}\text { Penicillium } \\
\text { chrysogenum }\end{array}$ & 14 & 18 & - & 31 \\
\hline $\begin{array}{l}\text { Penicillium } \\
\text { notatum }\end{array}$ & 15 & - & - & - \\
\hline Rhizopus stolonifer & 32 & 6 & 12 & 14 \\
\hline Rhizoctonia oryzae & 20 & 11 & 30 & 42 \\
\hline Trichoderma viride & 25 & 16 & - & 25 \\
\hline
\end{tabular}

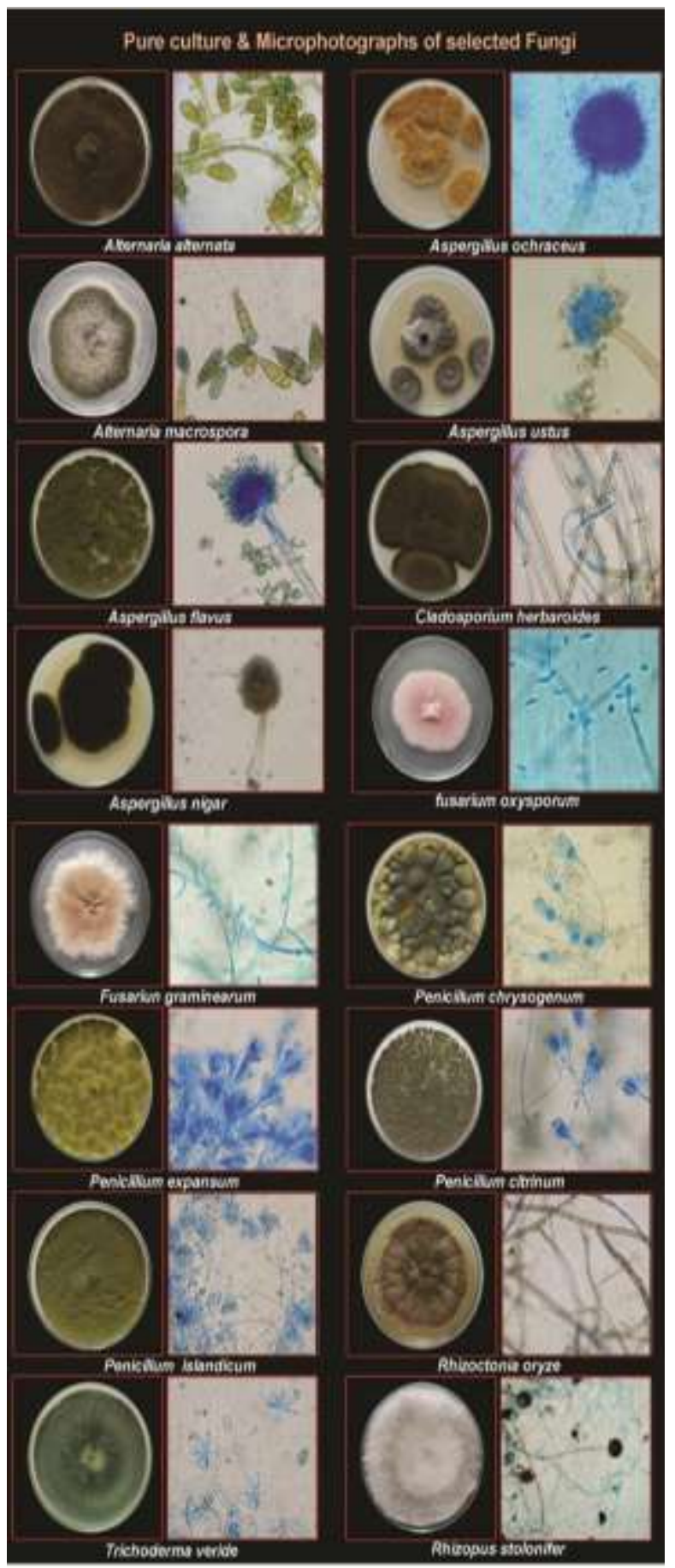


Table No. 3:- Effect of dominant seed-borne fungi on inhibition of seed germination, shoot and root length of maize (Zea mays) by blotter method (After 7 days of incubation).

\begin{tabular}{|c|c|c|c|c|}
\hline \multirow{2}{*}{$\begin{array}{l}\text { Sr. } \\
\text { No. }\end{array}$} & \multirow{2}{*}{ Infestation by dominant seed-borne fungi } & \multicolumn{3}{|l|}{ Seed health } \\
\hline & & $\begin{array}{l}\text { Seed } \\
\text { Germination }(\%)\end{array}$ & $\begin{array}{l}\text { Shoot } \\
\text { length } \\
(\mathrm{cm})\end{array}$ & $\begin{array}{l}\text { Root } \\
\text { length } \\
\text { (cm) }\end{array}$ \\
\hline 1 & Alternaria alternata & 40 & 1.9 & 3.0 \\
\hline 2 & Aspergillus flavus & 40 & 2.2 & 3.1 \\
\hline 3 & Aspergillus fumigatus & 50 & 2.0 & 2.2 \\
\hline 4 & Aspergillus niger & 25 & 1.5 & 3.0 \\
\hline 5 & Curvularia lunata & 50 & 2.0 & 2.5 \\
\hline 6 & Fusarium gramineorum & 70 & 3.0 & 3.8 \\
\hline 7 & Fusarium oxysporium & 60 & 2.0 & 2.4 \\
\hline 8 & Penicillium citrinum & 30 & 1.6 & 2.0 \\
\hline 9 & Rhizopus stolonifer & 80 & 2.2 & 2.2 \\
\hline 10 & Trichoderma viride & 35 & 2.1 & 3.8 \\
\hline & Control & 100 & 3.0 & 3.2 \\
\hline
\end{tabular}

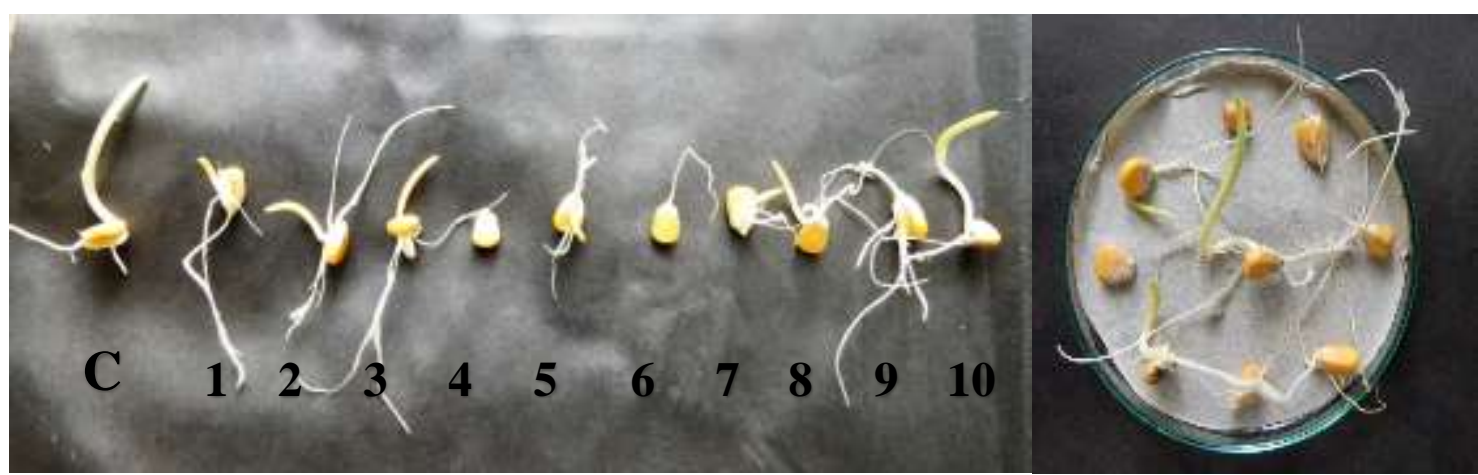

Seed germination, shoot and root length of maize (Zea mays) by blotter method

\section{Seed germination:-}

Effect of 10dominant seed-borne fungi was observed on seed germination of maize, results in table 3 show that, all dominant seed-borne fungi of cereal retarded percent seed germination shoot and root length in the test seed of pulse. Aspergillus niger caused maximum reduction in seed germination (25\%) followed by Aspergillus flavus (40 $\%$ ) and A. fumigatus (50\%). On the contrary Rhizopus stolonifer and Fusarium showed better seed germination (80 $\%$ and $70 \%$ respectively).

\section{References:-}

1. Laubscher, E. W. and Cairns, A.L. (1983). The effect of harvesting technique and storage procedure on the germination of barley. Crop Production, 12, 128-132.

2. Patil, P. J., Padule D. N., Suryawanshi J. S. and Pinjari S. S. (2008). Fungi associated with moldy sorghum [Sorghumbicolar (L) Moench] cv. CSH-9 in Western Maharashtra. International journal of plant protection, 1(2), 84-87

3. Panchal, V. H. and Dhale D. A. (2011). Isolation of seed borne fungi of sorghum (Sorghum vulgare pers.) Journal of phytopathology, 3(12), 45-48.

4. Singh, S. D. and Bandyopadhyay R. (2000). Grain mold. Pages 38-40 in Compendium of Sorghum Diseases. Second Edition, The American Phytopathological Society, (Frederiksen RA and dvody GN, Eds.). St.Paul, MN, USA. APS Pres

5. Thakur, R. P., Rao, V. P., Navi, S. S., Garud, T. B., Agarkar, G. D. and Bhat B. (2003). Sorghum Grain Mold: Variability in Fungal Complex. Intern. Sorghum and Millets Newsl., 44, 104-108

6. Janicki, L. J. and Green, V. E. (Jr). (1976). Rice losses during harvest drying and storage. II. Riso 25, 333-338. 
7. Christensen, C. M. and Kaufmann, H. H. (1969). Grain storage: The role of fungi in quality loss. University of Minnesota Press, Minneapolis, MN.

8. Christensen, C. M. and Kaufmann, H. H. (1974). Microflora. In Storage of Cereal Grain and Their Products. C. M. Christensen (Editor). American Association of Cereal Chemists, Inc., St. Paul, MN

9. Habib. A., Sahi S. T., Javed N., Ahmad S. (2011). Prevalence of seed-borne fungi on wheat during storage and its impact on seed germination. Pak. J. Phytopathol. 23(1), 42-47.

10. Mathur S. B., Kongsdal, O. (2003). Common laboratory seed health testing methods for detecting fungi. International Seed Testing Association, Bassersdorf, Switzerland, p. 427. 